\title{
Genetic structure of a Brazilian population of the begomovirus Tomato severe rugose virus (ToSRV)
}

\author{
Jorge González-Aguilera ${ }^{1}$, Sheila S. Tavares ${ }^{2,3}$, Roberto R. Sobrinho ${ }^{2}$, César A.D. Xavier ${ }^{2}$, Francisco \\ Dueñas-Hurtado ${ }^{2,4}$, Regla M. Lara-Rodrigues ${ }^{4}$, Derly J.H. da Silva ${ }^{1} \&$ F. Murilo Zerbini ${ }^{2}$
}

${ }^{1}$ Departamento de Fitotecnia, Universidade Federal de Viçosa, Viçosa, MG, 36570-000, Brazil; ${ }^{2}$ Departamento de Fitopatologia/ BIOAGRO, Universidade Federal de Viçosa, Viçosa, MG, 36570-000, Brazil; ${ }^{3}$ Departamento de Fitossanidade/CECA, Universidade Federal de Alagoas, Rio Largo, AL, 57100-000, Brazil; ${ }^{4}$ Genética y Mejora de Plantas, Instituto Nacional de Ciencias Agrícolas - INCA, La Habana, Cuba

Author for correspondence: F. Murilo Zerbini, e-mail: zerbini@ufv.br

\begin{abstract}
Begomoviruses are whitefly-transmitted single-stranded DNA viruses of great economic importance in the tropics and subtropics. Several begomovirus species have been reported in tomatoes in Brazil, but only a few predominate in the field, for unknown reasons. In this study begomovirus-infected tomato samples were collected in Viçosa, State of Minas Gerais, in Nov/2009 and Dec/2010. Viral genomes were amplified, cloned and sequenced. A total of 36 DNA-A components were obtained. Sequence comparisons indicated the presence of a single begomovirus, Tomato severe rugose virus (ToSRV), with pairwise identities between isolates ranging from 97.3 to $100 \%$. Subdivision tests indicated the existence of a single population. The analysis of variability descriptors indicated that the ToSRV population has a genetic variability similar to other begomovirus populations described in Brazil infecting tomato. Neutrality tests suggested the occurrence of purifying selection acting upon the population. Recombination analysis identified recombination events with begomoviruses from the weed species Sida micrantha. The wide distribution of ToSRV in the field and the detection of recombination indicate that continuous monitoring of viral populations in the field will be required to enable an efficient resistance-based control strategy for begomoviruses.
\end{abstract}

Key words: geminivirus, genetic variability, recombination.

Viruses belonging to the family Geminiviridae have a genome comprised of circular ssDNA molecules encapsidated in a twinned icosahedral capsid (Rojas et al., 2005). The family is divided into four genera (Mastrevirus, Curtovirus, Topocovirus and Begomovirus) according to the type of insect vector, host range, genome organization and phylogeny (Brown et al., 2012). Begomoviruses are transmitted by whiteflies (Bemisia tabaci - Homoptera: Aleyrodidae) and infect dicotyledonous plants. In Brazil, most begomoviruses are bipartite with two DNA components, DNA-A and DNA-B. For identification of a begomovirus isolate, the analysis of the full DNA-A sequence is essential.

In Brazil as well as in other countries in Latin America, the incidence and severity of the diseases caused by begomoviruses has greatly increased since the 1980's, due to the dissemination of aggressive biotypes of the whitefly vector (Lourenção \& Nagai, 1994; VillasBôas et al., 2002). As a result of the introduction and dissemination of B. tabaci biotype B in Brazil, a number of new begomovirus species have been described infecting tomatoes (Ribeiro et al., 2003; Castillo-Urquiza et al.,

The sequences described in this study have been deposited in GenBank under the accession numbers JX865615-JX865650.
2008; Fernandes et al., 2008). However, and in spite of the large number of begomovirus species described, only a few seem to predominate in the field, being detected in $>90 \%$ of the samples analyzed in field surveys (Cotrim et al., 2007; Castillo-Urquiza et al., 2008; Fernandes et al., 2008). Tomato severe rugose virus (ToSRV) is one of these "field-prevalent" begomoviruses (Colariccio et al., 2006; Fernandes et al., 2008; Barbosa et al., 2011; Rocha, 2011). In addition to tomato it also naturally infects pepper, potato and tobacco, and under experimental conditions it is capable of infecting at least nine weed species (SouzaDias et al., 2008; Barbosa et al., 2009; Nozaki et al., 2010; Barbosa et al., 2011). This broad host range may have important implications for disease management and development of resistant cultivars to ToSRV at the field level.

The study of geminivirus populations has assisted in the understanding of the evolution of these pathogens under field conditions (Prasanna et al., 2010; Ramos-Sobrinho et al., 2010; Rocha, 2011; Silva et al., 2011a, b). Such information is useful in the development of management strategies based on natural or engineered resistance, as it allows for a greater understanding of the evolutionary forces acting upon the pathogen (Prasanna et al., 2010).

The aim of this study was to determine the genetic make up of a population of ToSRV obtained from tomato 
samples collected over two years (2009 and 2010) in Viçosa, State of Minas Gerais.

Tomato samples showing typical symptoms of begomovirus infection were collected in November/2009 and December/2010 at an experimental field of Universidade Federal de Viçosa (UFV) (2045'14’S, 4252'53'”, 648 $\mathrm{m}$ elevation). DNA extraction was carried out from fresh leaves according to Dellaporta et al. (1983). The presence of begomoviruses was confirmed by non-radioactive molecular hybridization according to specifications of the Dig High Prime DNA Labeling and Detection Starter Kit II (Roche Applied Sciences). Full length viral genomes were amplified from positive samples by rolling-circle amplification (RCA) (Inoue-Nagata et al., 2004), cloned in pBLUESCRIPT KS+ (Stratagene) after monomerization with the restriction enzymes $B a m \mathrm{H} \mathrm{I}, C l a$ I and $K p n$ I and sequenced commercially (Macrogen, Seoul, South Korea).

DNA-A nucleotide sequences were initially submitted to a BLAST search for preliminary species assignment based on the $89 \%$ threshold level established by the Geminiviridae Study Group of the International Committee on Taxonomy of Viruses (Brown et al., 2011). Additional pairwise nucleotide sequence comparisons were made with DNAMan version 6.0 (Lynnon Biosoft Corporation) using the Optimal Alignment option with the following parameters: Ktuple $=2$, Gap penalty $=7$, Gap open $=10$, Gap extension $=5$. Nucleotide sequences of begomoviruses used in the recombination and phylogenetic analyses (Table 1) were aligned using the Muscle module in MEGA 5.0 (Tamura et al., 2011). A phylogenetic tree based on the DNA-A sequence alignment was constructed with MEGA 5.0 using the Neighbour-Joining method. Bootstrap analysis (10,000 replications) was carried out to verify the significance of each tree branch.

The program DnaSP version 5 (Librado \& Rojas, 2009) was used to determine the extent of genetic differentiation or level of gene flow between the two putative subpopulations (samples collected in Nov/2009

TABLE 1 - Begomoviruses used for pairwise sequence comparisons, phylogenetic and recombination analysis

\begin{tabular}{|c|c|c|}
\hline Species & Acronym & $\begin{array}{c}\text { GenBank access } \\
\text { number }\end{array}$ \\
\hline \multicolumn{3}{|l|}{ Brazil } \\
\hline Bean golden mosaic virus & BGMV & M88686 \\
\hline Blainvillea yellow spot virus & BlYSV & EU710756 \\
\hline Sida common mosaic virus & SiCmMV & EU710751 \\
\hline Sida micrantha mosaic virus & SiMMV & FJ686693 \\
\hline Sida mosaic Brazil virus & SiMBV & FN436001 \\
\hline Sida mottle virus & SiMoV & AY090555 \\
\hline Sida yellow leaf curl virus & SiYLCV & EU710750 \\
\hline Sida yellow mosaic virus & SiYMV & AY090558 \\
\hline Tomato chlorotic mottle virus & ToCMoV & AF490004 \\
\hline Tomato common mosaic virus & ToCmMV & EU710754 \\
\hline Tomato leaf distortion virus & ToLDV & EU710749 \\
\hline Tomato mild mosaic virus & ToMIMV & EU710752 \\
\hline Tomato rugose mosaic virus & ToRMV & AF291705 \\
\hline Tomato severe rugose virus & ToSRV & DQ207749 \\
\hline Tomato severe rugose virus & ToSRV & HQ606467 \\
\hline Tomato severe rugose virus & ToSRV & FJ824808 \\
\hline Tomato yellow spot virus & ToYSV & DQ336350 \\
\hline Tomato yellow vein streak virus & ToYVSV & EF417915 \\
\hline \multicolumn{3}{|l|}{ Others countries of the Americas } \\
\hline Sida golden yellow vein virus & SiGYVV & AJ577395 \\
\hline Sida yellow mosaic Yucatan virus & SiYMYuV & DQ875872 \\
\hline Sida yellow vein virus & SiYVV & Y11099 \\
\hline Tomato Chino La Paz virus & ToChLPV & AY339618 \\
\hline Tomato golden motlle virus & ToGMoV & AF132852 \\
\hline Tomato mosaic Havana virus & ToMHV & EF088197 \\
\hline Tomato mottle Taino virus & ToMoTV & AF012300 \\
\hline Tomato mottle virus & ToMoV & AY965900 \\
\hline Tomato severe leaf curl virus & ToSLCV & AF130415 \\
\hline Tomato leaf curl Sinaloa virus & ToLCSV & AJ608286 \\
\hline Tomato leaf curl Cuba virus & ToLCCUV & AM050143 \\
\hline Tomato yellow leaf distortion virus & ToYLDV & FJ174698 \\
\hline \multicolumn{3}{|l|}{ Old World } \\
\hline Tomato leaf curl New Delhi virus & ToLCNDV & U15015 \\
\hline
\end{tabular}


and in Dec/2010) using Wright's Fst value (Wright, 1951). Wright's Fst is a measure of the proportion of total genetic variation contained in a subpopulation relative to the total genetic variation. Values can range between 0 and 1 and Fst values $>0.05(5 \%)$ suggest a degree of differentiation between subpopulations.

The main descriptors of genetic variability were quantified: number of polymorphic sites (S), total number of mutations (Eta), average number of nucleotide differences $(\mathrm{k})$, nucleotide diversity $(\pi)$, mutation frequency, number of haplotypes $(\mathrm{H})$, haplotype diversity $(\mathrm{Hd})$, Watterson's estimate of the population mutation rate based on the total number of segregating sites $(\theta \mathrm{w}-\mathrm{S})$ and on the total number of mutations ( $\theta$-Eta). The analysis was performed using DnaSP version 5. The sequences of each ORF in the DNA-A (CP, capsid protein; Rep, replication-associated protein; Trap, trans-activating protein; Ren, replication-enhancer protein; and AC4) were aligned using the Muscle module in MEGA 5.0. Tajima's $D$ (Tajima, 1989) and Fu and Li's $D^{*}$ and $F^{*}$ (Fu \& Li, 1993) were computed for each ORF using DnaSP version 5.

Phylogenetic network analysis for evidence of recombination was performed among ToSRV isolates (including the ones obtained in Viçosa) with the NeighborNet method implemented in the program SplitsTree4 (Huson \& Bryant, 2006). Analysis of potential recombination events was carried out using the Recombination Detection Program (RDP) version 3.0 (Martin et al., 2010) using default parameters. To omit unreliable signals, only recombination events supported by at least four different methods were considered. The dataset included some of the isolates obtained in this study and other begomoviruses previously described. Some of the isolates of ToSRV were excluded of the dataset after analysis of the minimum genetic distance threshold recommended in the RDP manual.

The percentage of tomato and weed plants displaying symptoms of begomovirus infection at the collection site was very high on both years, as well as the level of whitefly infestation. This site has been used for screening material from UFV's tomato breeding program for begomovirus resistance (Xavier et al., 2011). A total of 65 tomato samples were collected: 28 in Nov/2009 and 37 in Dec/2010. All samples were positive for the presence of begomoviruses based on non-radioactive molecular hybridization (data not shown). A total of 36 full-length DNA-A components were cloned. Clones were named according to the recommendations of the Geminiviridae Study Group of the ICTV (Fauquet et al., 2008): country code:isolate reference:year of collection (eg, BR:Vic1:09).

BLAST analysis and pairwise sequence comparisons of the DNA-A clones indicated that they all corresponded to isolates of the species Tomato severe rugose virus (ToSRV), with nucleotide sequence identities between isolates ranging from 97.3 to $100 \%$. These results were confirmed by phylogenetic analysis, in which all isolates clustered in a single branch with previously sequenced ToSRV isolates
(GenBank accession numbers DQ207749, FJ824808 and HQ606467), supported by a bootstrap value of $100 \%$ (data not shown). Moreover, all ToSRV isolates, including the ones described here, formed a group with begomoviruses previously reported in Brazil, which diverged from another group of begomoviruses described from other American countries (data not shown). The detection of a single begomovirus may be related to the fact that all clones were obtained with the same enzyme $(\operatorname{BamH} \mathrm{I})$. Although most of the begomoviruses described infecting tomatoes in Brazil possess a unique $B a m H$ I site either in the DNA-A or in the DNA-B, one particular virus which has been commonly detected in the region, Tomato common mosaic virus (ToCmMV), does not. Thus, it is possible that the true diversity of begomoviruses present in that field was not represented, and it is not possible to claim that ToSRV is the only begomovirus present at the sampled site. Additional clones should be obtained using different enzymes in order to verify (or rule out) the presence of other begomoviruses.

The ToSRV isolates were initially divided into two putative subpopulations according to the date of collection (Nov/2009 or Dec/2010). However, the value obtained for the Fst test (0.036) indicated that these two putative subpopulations were actually not structured. Therefore they were treated as a single population comprised of 36 DNA-A clones.

The ToSRV population obtained here, when compared with two other ToSRV populations also obtained from tomatoes in Minas Gerais (municipalities of Florestal and Carandaí) (Rocha, 2011), has shown a similar genetic variability. This could be related to the proximity of the collecting sites ( $c a .100 \mathrm{~km}$ between Viçosa and Carandaí, $230 \mathrm{~km}$ between Viçosa and Florestal, and $150 \mathrm{~km}$ between Florestal and Carandaí). Nevertheless, there was a large time span between sample collection: samples from Carandaí and Florestal were collected in Jul/2008, 17 and 29 months before the samples from Viçosa. When compared with populations of ToCmMV and Tomato yellow vein streak virus (ToYVSV) from tomato (Castillo-Urquiza, 2008), Bean golden mosaic virus (BGMV) from lima bean (RamosSobrinho et al., 2010), Cleome leaf crumple virus (ClLCrV) from Cleome affinis (Silva et al., 2011a) and Macroptilium yellow spot virus (MaYSV) from Macroptilium spp. (Silva et al., 2011b), the genetic variability was lower for the ToSRV population. The ClLCrV and MaYSV population showed greater genetic variability (Table 2).

The genetic variability of the ToSRV population from this work was similar to those from two other ToSRV populations obtained from tomatoes in Minas Gerais (Rocha, 2011). Conversely, the variability of these ToSRV populations is much lower than those from begomovirus populations infecting lima bean or weeds (Ramos-Sobrinho et al., 2010; Silva et al., 2011a, b). A low degree of genetic variability could be a feature of ToSRV populations. However, we favor a hypothesis based on all ToSRV populations being sampled from the same host (tomato), 
Genetic structure of a Brazilian population of the begomovirus Tomato severe rugose virus (ToSRV)

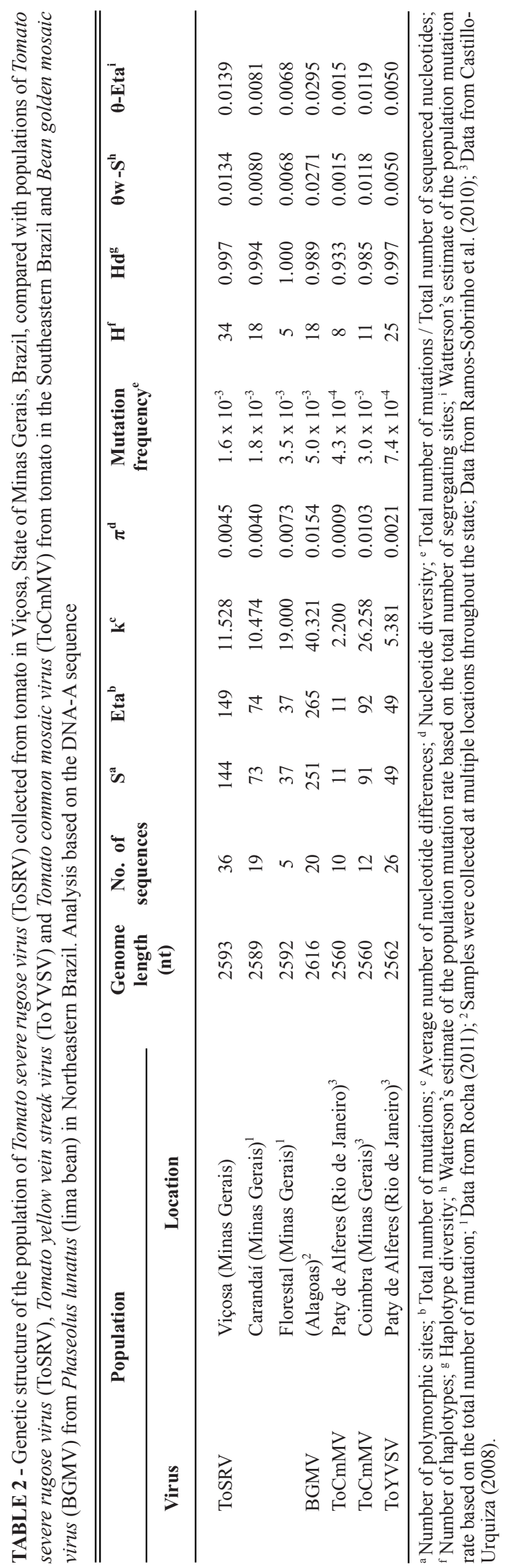


which also has a narrow genetic basis. In other words, the genetic variability of begomovirus populations could be modulated by the genetic variability of the host. Since ToSRV is known to infect multiple hosts, including crops such as peppers, and weeds such Nicandra physaloides and Solanum nigrum (Cotrim et al., 2007; Barbosa et al., 2009; Nozaki et al., 2010; Barbosa et al., 2011), which supposedly have distinct genetic bases, this hypothesis could be tested by analyzing ToSRV populations obtained from these different hosts.

Neutrality tests were applied to assess whether there was evidence of selection on genomic regions encoding the CP, Rep, Ren, Trap and AC4 ORFs. Values for Tajima's $D$ and $\mathrm{Fu}$ and $\mathrm{Li}$ 's $D^{*}$ and $F^{*}$ tests were negative for all ORFs, but were not significant for Trap and AC4 (except for Fu and Li's $F^{*}$ for AC4; Table 3 ). These results indicate that purifying selection is acting upon all ORFs in the DNA-A of the ToSRV population from tomato, coinciding with the

TABLE 3 - Neutrality tests based on variation in the CP, Rep, Ren, Trap and AC4 ORFs of the isolates of Tomato severe rugose virus (ToSRV) collected from tomato samples in Viçosa, State of Minas Gerais, Brazil

\begin{tabular}{llllll}
\hline \hline Tests/ORFs & CP & Rep & Ren & Trap & AC4 \\
\hline Tajima's $D$ & $-4.56^{*}$ & $-3.16^{*}$ & $-3.33^{*}$ & $-0.46^{\mathrm{NS}}$ & $-1.78^{\mathrm{NS}}$ \\
Fu and Li's $D^{*}$ & $-4.62^{*}$ & $-3.39^{*}$ & $-3.35^{*}$ & $-0.86^{\mathrm{NS}}$ & $-2.17^{\mathrm{NS}}$ \\
Fu and Li's $F^{*}$ & $-2.61^{* *}$ & $-2.29^{* *}$ & $-2.37^{* *}$ & $-1.45^{\mathrm{NS}}$ & $-1.96^{*}$ \\
\hline
\end{tabular}

* Significant values, $P<0.05$

** Significant values, $P<0.01$

Ns Non significant values results obtained by Rocha (2011). During the viral infection cycle, several factors may impose purifying selection on the population. The biology of the vector and its feeding habits create bottlenecks for the maintenance of structural and functional characteristics of the viral proteins. Interaction with host factors may also impose purifying selection (García-Arenal et al., 2001).

Phylogenetic relationships inferred by neighbornet analysis based on a data set consisting of the three previously reported ToRSV isolates (DQ207749, FJ824808 and HQ606467) plus the ToSRV population described here, revealed evidence of multiple recombination events (Figure 1). To investigate these putative recombination signals in greater detail, a data set including additional sequences of Brazilian begomoviruses was analyzed using the RDP3 package. This analysis identified many unique recombination signals (Table 4), including two recombination events for the ToSRV isolates described here. The first event was observed for all isolates, encompassing nucleotides 1,910 to 2,135 (within the Rep and AC4 ORFs), with Sida micrantha mosaic virus (SiMMV) (AJ557451) and other unknown begomovirus as putative parents. The second event was detected for isolate BR:Vic30:10, encompassing nucleotides 1,910 to 2,166 (also within the Rep and AC4 ORFs) with the same putative parents of the other event (Table 4). Additionally, the isolate BR:Vic20:10 and Bean golden mosaic virus (BGMV) (M88686) were identified as putative parents in a recombination event involving Tomato rugose mosaic virus (ToRMV) (AF291705) with breakpoints located at nucleotides 1,520 and 2,596 (Rep ORF and common region) (Table 4; Figure 2). Lefeuvre et al. (2007a)

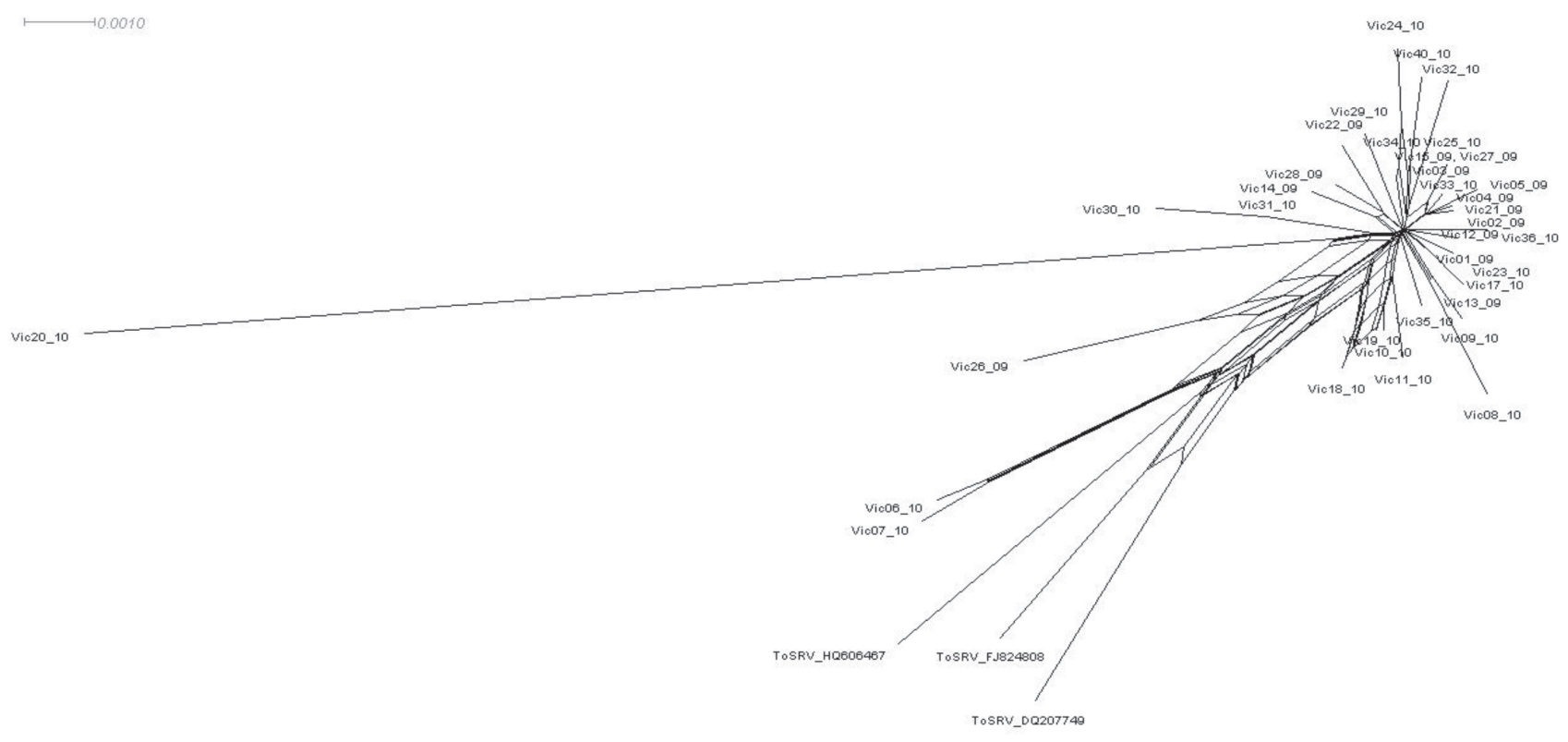

FIGURE 1 - Phylogenetic evidence for recombination among ToSRV (Tomato severe rugose virus) isolates, including the ones obtained in Viçosa, State of Minas Gerais, Brazil. Neighbor-net analysis was performed using the program SplitsTree4. Formation of a reticular network instead of a single forked tree is suggestive of recombination. 
TABLE 4 - Recombination events detected between begomoviruses previously described in Brazil and the isolates of Tomato severe rugose virus (ToSRV) from Viçosa, State of Minas Gerais, Brazil

\begin{tabular}{|c|c|c|c|c|c|c|}
\hline \multirow[t]{2}{*}{ Recombinants } & \multicolumn{2}{|c|}{ Breakpoints } & \multicolumn{2}{|c|}{ Parents } & \multirow[t]{2}{*}{ Programs $^{1}$} & \multirow[t]{2}{*}{$P$-value } \\
\hline & Initial & Final & Major & Minor & & \\
\hline BR:Vic01:09, BR:Vic06:10, BR:Vic20:10 & 1,910 & 2,135 & Unknown & SiMMV(AJ557451) & RGBMCS & $5.2 \times 10^{-16}$ \\
\hline BR:Vic30:10 & 1,910 & 2,166 & Unknown & SiMMV(AJ557451) & RGBMCS & $5.2 \times 10^{-16}$ \\
\hline ToRMV (AF291705) & 1,520 & 2,596 & BGMV(M88686) & BR:Vic20:10 & $\mathrm{RGBMC} \underline{\mathrm{G}} 3$ & $1.9 \times 10^{-32}$ \\
\hline ToSRV (DQ207749) & 1,910 & 2,135 & Unknown & SiMMV(AJ557451) & RGBMCS & $5.2 \times 10^{-16}$ \\
\hline ToSRV (FJ824808) & 1,910 & 2,135 & Unknown & SiMMV(AJ557451) & RGBMCS & $5.2 \times 10^{-16}$ \\
\hline ToSRV (HQ606467) & 1,910 & 2,135 & Unknown & SiMMV(AJ557451) & RÉ $\underline{\bar{G} B M C S}$ & $5.2 \times 10^{-16}$ \\
\hline
\end{tabular}

${ }^{1}$ Programs that detected recombination events: $\mathrm{R}=\mathrm{RDP}$; $\mathrm{G}=$ GeneConv; $\mathrm{B}=$ Bootscan; $\mathrm{M}=$ MaxChi; $\mathrm{C}=\mathrm{CHIMAERA}$; $=$ SisScan; 3=3SEQ. The program underlined yielded the lowest $P$-value.

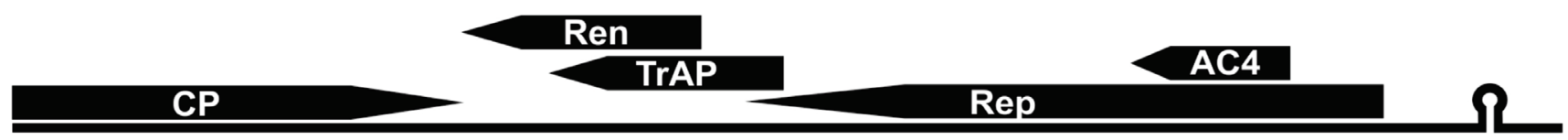

BR:Vic01:09

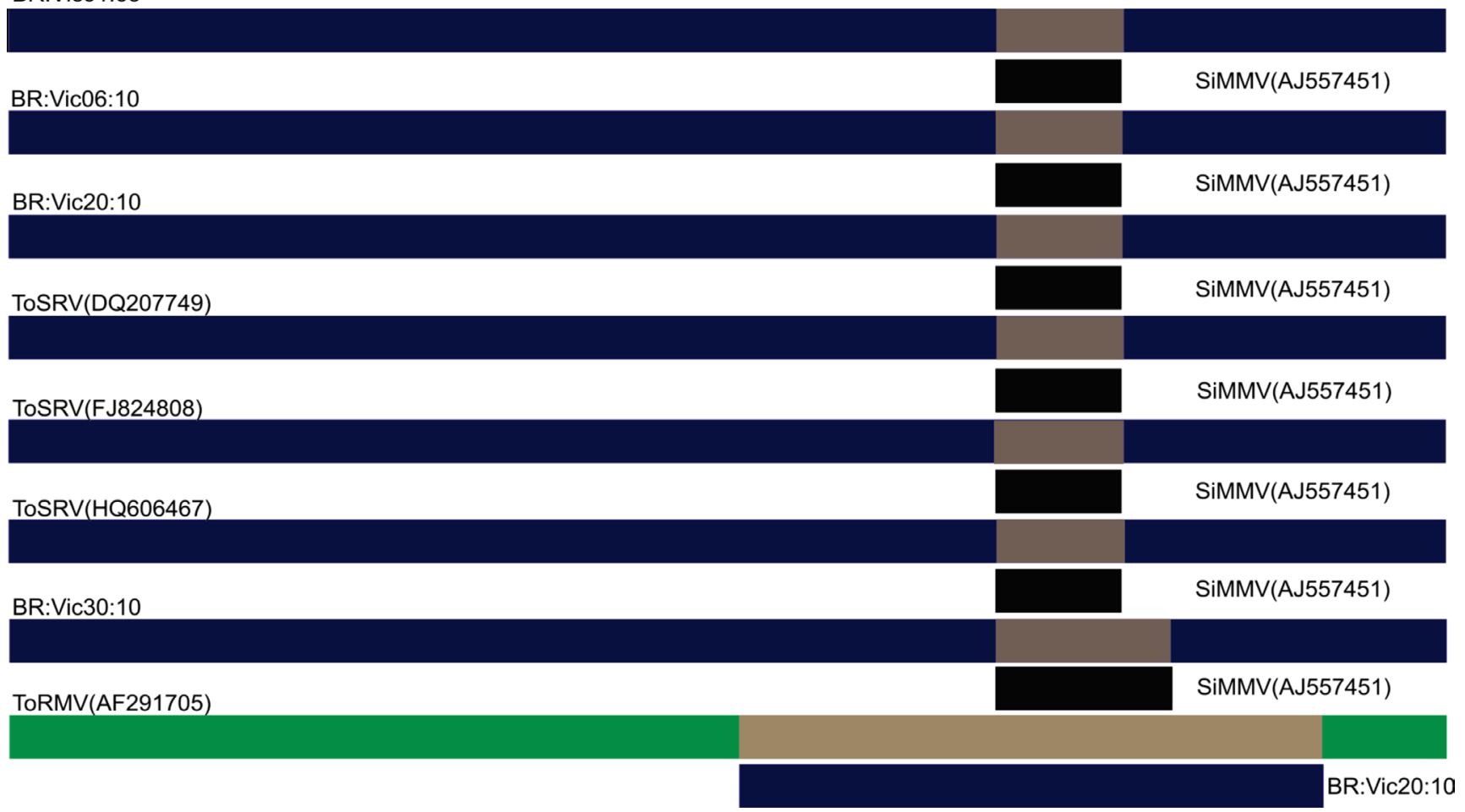

FIGURE 2 - Evidence of recombination among ToSRV isolates. Blue boxes represent the DNA-A sequences of the ToSRV isolates and black or brown boxes represent the regions of sequence with a potentially recombinant origin. Black boxes indicate recombinant region from minor parent detected with a high probability $(P<0.05)$ by at least four methods.

suggested that coding regions are generally less susceptible to recombination due to structural bottlenecks. However, the regions encoding the Rep and $\mathrm{CP}$ of begomoviruses have been shown to be hotspots of recombination (GarcíaAndrés et al., 2007; Lefeuvre et al., 2007b), coinciding with the results obtained in our study.

Several studies have shown that recombination is a common source of genetic variability for begomoviruses in
Brazil (Galvão et al., 2003; Inoue-Nagata et al., 2006) and worldwide (Pita et al., 2001; Monci et al., 2002; GarcíaAndrés et al., 2007). Recombination events detected in this work showed that viruses detected mostly in weeds (SiMMV) have recombined with others viruses, possibly giving rise to isolates which are better adapted to tomato.

The wide distribution of ToSRV in the State of Minas Gerais and its low degree of genetic variability have 
important implications for the development of disease management strategies based on genetic resistance. The evolutionary processes on these populations were little influenced by environmental factors such as geographical distance, temperature or altitude. A low degree of variability in the viral population could facilitate the obtainment of durable resistance, as long as there are no natural reservoirs where more diverse populations could be hiding.

\section{ACKNOWLEDGMENTS}

This work was funded by Coordenação de Aperfeiçoamento de Pessoal de Nível Superior - CAPES, under the framework of the Brazil-Cuba Bilateral Cooperation Program (CAPES-MES grant 067/09 to DJHS) and by Fundação de Amparo à Pesquisa do Estado de Minas Gerais - FAPEMIG grant CAG 949/09 to FMZ. The first author was recipient of a FAPEMIG doctoral fellowship.

\section{REFERENCES}

Barbosa JC, Barreto SD, Inoue-Nagata AK, Rezende JAM (2011) Characterization and experimental host range of a Brazilian tomato isolate of Tomato severe rugose virus. Journal of Phytopathology 159:644-646.

Barbosa JC, Barreto SS, Inoue-Nagata AK, Reis MS, Firmino AC, Bergamin Filho A, Rezende JAM (2009) Natural infection of Nicandra physaloides by Tomato severe rugose virus in Brazil. Journal of General Plant Pathology 75:440-443.

Brown JK, Fauquet CM, Briddon RW, Zerbini FM, Moriones E, Navas-Castillo J (2012) Family Geminiviridae. In: King AMQ, Adams MJ, Carstens EB, Lefkowitz EJ (Eds.) Virus Taxonomy. 9th Report of the International Committee on Taxonomy of Viruses. London UK. Elsevier Academic Press. pp. 351-373.

Castillo-Urquiza GP (2008) Diversidade e estrutura genética de begomovírus em duas regiões produtoras de tomate do Sudeste do Brasil. D.S. Thesis, Universidade Federal de Viçosa. Viçosa MG.

Castillo-Urquiza GP, Beserra Jr. JEA, Bruckner FP, Lima ATM, Varsani A, Alfenas-Zerbini P, Zerbini FM (2008) Six novel begomoviruses infecting tomato and associated weeds in Southeastern Brazil. Archives of Virology 153:1985-1989.

Colariccio A, Bergmann JC, Eiras M, Chaves ALR, Chagas CM, Zerbini FM (2006) Tomato rugose mosaic virus in tomato crops in São Paulo State, Brazil. Fitopatologia Brasileira 31:606.

Cotrim MA, Krause-Sakate R, Narita N, Zerbini FM, Pavan MA (2007) Diversidade genética de begomovírus em cultivos de tomateiro no Centro-Oeste Paulista. Summa Phytopathologica 33:300-303.

Dellaporta SL, Wood J, Hicks JB (1983) A plant DNA minipreparation: Version II. Plant Molecular Biology Reporter $1: 19-21$.

Fauquet CM, Briddon RW, Brown JK, Moriones E, Stanley J, Zerbini FM, Zhou X (2008) Geminivirus strain demarcation and nomenclature. Archives of Virology 153:783-821.

Fernandes FR, Albuquerque LC, Giordano LB, Boiteux LS, Ávila AC, Inoue-Nagata AK (2008) Diversity and prevalence of
Brazilian bipartite begomovirus species associated to tomatoes. Virus Genes 36:251-258.

Fu Y, Li WH (1993) Statistical tests of neutrality of mutations. Genetics 133:693-709.

Galvão RM, Mariano AC, Luz DF, Alfenas PF, Andrade EC, Zerbini FM, Almeida MR, Fontes EPB (2003)A naturally occurring recombinant DNA-A of a typical bipartite begomovirus does not require the cognate DNA-B to infect Nicotiana benthamiana systemically. Journal of General Virology 84:715-726.

García-Andrés S, Tomas DM, Sanchez-Campos S, Navas-Castillo J, Moriones E (2007) Frequent occurrence of recombinants in mixed infections of tomato yellow leaf curl disease-associated begomoviruses. Virology 365:210-219.

García-Arenal F, Fraile A, Malpica JM (2001) Variability and genetic structure of plant virus populations. Annual Review of Phytopathology 39:157-186.

Huson DH, Bryant D (2006) Application of phylogenetic networks in evolutionary studies. Molecular Biology and Evolution 23:254267.

Inoue-Nagata AK, Albuquerque LC, Rocha WB, Nagata T (2004) A simple method for cloning the complete begomovirus genome using the bacteriophage phi 29 DNA polymerase. Journal of Virological Methods 116:209-211.

Inoue-Nagata AK, Martin DP, Boiteux LS, Giordano LD, Bezerra IC, de Avila AC (2006) New species emergence via recombination among isolates of the Brazilian tomato infecting Begomovirus complex. Pesquisa Agropecuária Brasileira 41:1329-1332.

Lefeuvre P, Lett JM, Reynaud B, Martin DP (2007a) Avoidance of protein fold disruption in natural virus recombinants. PLoS Pathogens 3:e181.

Lefeuvre P, Martin DP, Hoareau M, Naze F, Delatte H, Thierry M, Varsani A, Becker N, Reynaud B, Lett JM (2007b) Begomovirus 'melting pot' in the south-west Indian Ocean islands: Molecular diversity and evolution through recombination. Journal of General Virology 88:3458-3468.

Librado P, Rozas J (2009) DnaSP v5: A software for comprehensive analysis of DNA polymorphism data. Bioinformatics 25:14511452.

Lourenção AL, Nagai H (1994) Surtos populacionais de Bemisia tabaci no Estado de São Paulo. Bragantia 53:53-59.

Martin DP, Lemey P, Lott M, Moulton V, Posada D, Lefeuvre P (2010) RDP3: A flexible and fast computer program for analyzing recombination. Bioinformatics 26:2462-2463.

Monci F, Sanchez-Campos S, Navas-Castillo J, Moriones E (2002) A natural recombinant between the geminiviruses Tomato yellow leaf curl Sardinia virus and Tomato yellow leaf curl virus exhibits a novel pathogenic phenotype and is becoming prevalent in Spanish populations. Virology 303:317-326.

Morales FJ, Jones PG (2004) The ecology and epidemiology of whitefly-transmitted viruses in Latin America. Virus Research 100:57-65.

Nozaki DN, Krause-Sakate R, Pavan MA (2010) Begomovírus infectando a cultura de pimentão no estado de São Paulo. Summa Phytopathologica 36:244-247.

Pita JS, Fondong VN, Sangare A, Otim-Nape GW, Ogwal S, Fauquet CM (2001) Recombination, pseudorecombination and

Tropical Plant Pathology 37 (5) September - October 2012 
synergism of geminiviruses are determinant keys to the epidemic of severe cassava mosaic disease in Uganda. Journal of General Virology 82:655-665.

Prasanna HC, Sinha DP, Verma A, Singh M, Singh B, Rai M, Martin DP (2010) The population genomics of begomoviruses: Global scale population structure and gene flow. Virology Journal 7:220.

Ramos-Sobrinho R, Silva SJC, Silva TAL, Ribeiro SG, Lima GSA, Assunção IP, Zerbini FM (2010) Genetic structure of a population of the begomovirus Bean golden mosaic virus (BGMV) that infects lima bean (Phaseolus lunatus L.) in the state of Alagoas, Brazil. In: 6th International Geminivirus Symposium and 4th International ssDNA Comparative Virology Workshop, Abstracts. Guanajuato, Mexico.

Ribeiro SG, Ambrozevicius LP, Ávila AC, Bezerra IC, Calegario RF, Fernandes JJ, Lima MF, Mello RN, Rocha H, Zerbini FM (2003) Distribution and genetic diversity of tomato-infecting begomoviruses in Brazil. Archives of Virology 148:281-295.

Rocha CS (2011) Variabilidade e estrutura genética de populações de begomovírus em tomateiro e plantas daninhas em seis localidades do sudeste brasileiro. D.S. Thesis, Universidade Federal de Viçosa. Viçosa MG.

Rojas MR, Hagen C, Lucas WJ, Gilbertson RL (2005) Exploiting chinks in the plant's armor: Evolution and emergence of geminiviruses. Annual Review of Phytopathology 43:361-394.

Silva SJC, Castillo-Urquiza GP, Hora-Júnior BT, Assunção IP, Lima GSA, Pio-Ribeiro G, Mizubuti ESG, Zerbini FM (2011a) High genetic variability and recombination in a begomovirus population infecting the ubiquitous weed Cleome affinis in Northeastern Brazil. Archives of Virology 156:2205-2213.

Silva SJC, Castillo-Urquiza GP, Hora-Júnior BT, Assunção IP, Lima GSA, Pio-Ribeiro G, Mizubuti ESG, Zerbini FM (2011b) Species diversity, phylogeny and genetic variability of begomovirus populations infecting leguminous weeds in Northeastern Brazil. Plant Pathology 61:457-467.

Souza-Dias JAC, Sawazaki HE, Pernambuco PCA, Elias LM, Maluf H (2008) Tomato severe rugose virus: Another begomovirus causing leaf deformation and mosaic symptoms on potato in Brazil. Plant Disease 92:487-488.

Tajima F (1989) Statistical method for testing the neutral mutation hypothesis by DNA polymorphism. Genetics 123:585-595.

Tamura K, Peterson D, Peterson N, Stecher G, Nei M, Kumar S (2011) MEGA5: Molecular evolutionary genetics analysis using maximum likelihood, evolutionary distance, and maximum parsimony methods. Molecular Biology and Evolution 28: 27312739.

Villas-Bôas GL, França FH, Macedo N (2002) Potencial biótico da mosca-branca Bemisia argentifolii a diferentes plantas hospedeiras. Horticultura Brasileira 20:71-79.

Wright S (1951) The genetical structure of populations. Annals of Eugenics 15:323-354.

Xavier CAD, Aguilera JG, Laurindo BS, Freitas RD, Soares MO, Silva DJH, Zerbini FM (2011) Avaliação de subamostras de tomate para resistência a geminívirus em condições de campo com infecção natural. In: $51^{\circ}$ Congresso Brasileiro de Olericultura, Resumos... Viçosa MG. Sociedade Brasileira de Olericultura.

TPP 465 - Received 27 December 2011 - Accepted 6 July 2012 Section Editor: Alice K. Inoue-Nagata 